\title{
PENERAPAN ASUHAN KEPERAWATAN PASIEN DIARE DALAM GANGGUAN PEMENUHAN KEBUTUHAN ELIMINASI
}

\author{
The application of nursing care to patient with diarrhea in the fishering needs of elimination \\ Ratna Mahmud \\ Prodi D III Keperawatan Fakultas Kedokteran Dan IImu Kesehatan Unismuh Makassar \\ Email : ratnamahmud@gmail.com / Hp 081342066867
}

\begin{abstract}
ABSTRAK
Latar Belakang: Diare merupakan buang air besar dalam bentuk cairan lebih dari tiga kali dalam satu hari, dan biasanya berlangsung selama dua hari atau lebih. Pada kasus Diare terjadi perubahan pada pola eliminasi fekal berupa penurunan penyerapan di dalam usus. Diare merupakan penyakit yang dapat mengenai semua kelompok umur, khususnya di kalangan anak - anak kurang dari 5 tahun. Berdasarkan data Riskesdas tahun 2018, prevalensi Diare pada balita di Indonesia mengalami peningkatan yang cukup besar. Tujuan: Menggambarkan asuhan keperawatan pada pasien anak dengan Diare dalam gangguan pemenuhan kebutuhan pola eliminasi BAB. Metode: menggunakan metode deskriptif. Hasil: Pasien dengan kasus diare didapatkan data ibu klien mengatakan klien BAB sebanyak 5x. Ibu klien mengatakan BAB klien berbentuk encer, terdapat ampas dan berwarna coklat. Ibu klien mengatakan klien mengeluh sakit perut. Ibu klien juga mengatakan klien muntah-muntah sebanyak 7 kali. Intervensi keperawatan mengkaji warna, frekuens, konsistensi tinja, mengidentifikasi penyebab, terapi intra vena edukadi pada keluarga dan pemberian obat antidiare, antibiotic dan antipieretik sangat membantu dalam penangan pola eliminasi diare Kesimpulan: Pada diagnosa keperawatan gangguan pola eliminasi : Diare berhubungan dengan proses infeksi tindakan observasi karakteristik tinja, penyebab diare, observasi peristaltic usus, kolaborasi intra vena dan obat memberi pengaruh dalam mengatasi diare. Saran: Agar mendapatkan hasil yang optimal dalam pengkajian dan penetapan diagnosa, maka terlebih dahulu sebaiknya lakukan pendekatan interpersonal sehingga terbiana hubungan saling percaya antara pasien dan keluarga dengan perawat. Sebaiknya perawat melibatkan pasien dan keluarga dalam pelaksanaan tindakan keperawatan.
\end{abstract}

Kata kunci : Askep, Diare, Eliminasi

\section{ABSTRACT}

Background: Diarrhea is a bowel movement in liquid form more than three times a day, and usually lasts for two days or more. In the case of diarrhea there is a change in the pattern of faecal elimination in the form of decreased absorption in the intestine. Diarrhea is a disease that can affect all age groups, especially among children less than 5 years old. Based on the 2018 Riskesdas data, the prevalence of diarrhea in infants in Indonesia has increased quite significantly. Objective: To describe nursing care in pediatric patients with diarrhea in impaired fulfillment of the need for bowel elimination patterns. Method: using descriptive method. Results: Patients with diarrhea cases obtained data from the client's mother said the client defecated as much as 5x. The client's mother said the client's stool was thin, there was pulp and brown. The client's mother said the client complained of stomach pain. The client's mother also said the client vomited 7 times. Interventions assessing the color, frequency and consistency of stool, identifying causes and intravenous therapy are very helpful in handling diarrhea elimination patterns. Conclusion: In nursing diagnoses, disorders of elimination pattern: Diarrhea is related to the infection process, observing stool characteristics, causes of diarrhea, intestinal peristaltic observation, intra collaboration veins education and drugs , antipieretik, antibiotic and antiadiarhea have an influence in dealing with diarrhea. Suggestion: In order to obtain optimal results in the assessment and determination of diagnoses, it is better to do an interpersonal approach so that there is a trusting relationship between the patient and family and the nurse. The nurse should involve the patient and family in implementing nursing actions.

Keywords: Askep, Diarrhea, Elimination

\section{PENDAHULUAN}

Salah satu penyakit akibat gangguan sistem pencernaaan yang sering ditemukan pada anak adalah Diare. Diare merupakan gejala yang terjadi karena kelainan yang melibatkan fungsi pencernaan, penyerapan, dan sekresi. Diare disebabkan oleh transportasi air dan elektrolit yang abnormal dalam usus. (Wong, 2009).Menurut WHO, Diare merupakan buang air besar dalam bentuk cairan lebih dari tiga kali dalam satu hari, dan biasanya berlangsung selama dua hari atau lebih. Menurut Sudoyo (2006), Diare merupakan buang air besar (defekasi) dengan 
tinja berbentuk cair (setengah padat), kandungan air lebih banyak dari biasanya lebih dari 200 gram atau $200 \mathrm{ml} / 24$ jam. Sedangkan menurut Hendarwanto (2002) dalam Sipahutar (2008) diare adalah buang air besar (defekasi) dengan tinja berbentuk cairan atau setengah cairan, dengan demikian kandungan air pada tinja lebih banyak dari keadaan normal yakni 100-200 ml sekali defekasi (Wijaya \& Putri, 2013).

Pada kasus Diare terjadi perubahan pada pola eliminasi fekal. Perubahan tersebut berupa penurunan penyerapan di dalam usus. Eliminasi merupakan kebutuhan dasar manusia yang esensial dan berperan penting untuk kelangsungan hidup manusia. Eliminasi dibutuhkan untuk mempertahankan keseimbangan fisiologis melalui pembuangan sisa-sisa metabolisme, sehingga apabila hal tersebut terganggu maka akan mempengaruhi keseimbangan dalam tubuh dan mengganggu kelangsungan hidup manusia (Artha, Indra, \& Rasyid, 2018).

Gangguan pola elminasi fekal dimana dalam hal ini Diare merupakan penyakit yang dapat mengenai semua kelompok umur, khususnya di kalangan anak - anak kurang dari 5 tahun. Diare bahkan merupakan penyakit potensial Kejadian Luar Biasa (KLB) yang sering disertai dengan kematian. Hal ini yang kemudian membuat banyak peneliti menjadikan Diare sebagai bahan penelitian. Bahkan kasus Diare menjadi salah satu perhatian dari organisasi dunia. Data WHO (2017) menyatakan bahwa secara global, ada hampir 1,7 miliar kasus penyakit Diare anakanak setiap tahun. Penyakit Diare adalah penyebab utama kematian kedua pada anak di bawah lima tahun, dan membunuh sekitar 525.000 anak setiap tahunnya.

Diare merupakan penyebab utama kesakitan dan kematian pada anak di negara berkembang, dengan perkiraan 1,3 miliar episode dan 3,2 juta kematian setiap tahun pada balita. Kurang lebih $80 \%$ kematian yang berhubungan dengan Diare terjadi pada 2 tahun pertama kehidupan (Sodikin, 2011).Berdasarkan data Riskesdas tahun 2018, prevalensi Diare pada balita di Indonesia mengalami peningkatan yang cukup besar. Pada tahun 2013, prevalensi Diare pada balita $2.4 \%$, kemudian meningkat drastis pada tahun 2018 yaitu sebanyak $11 \%$. Wilayah provinsi Sulawesi Selatan sendiri turut mengalami peningkatan prevalensi Diare pada balita, yaitu pada tahun 2013 sebanyak $2 \%$ meningkat pada tahun 2018 menjadi $9.5 \%$ (Kemenkes, 2018).

Berdasarkan penelitian dari Fatmawati (2017), anak-anak usia 3 - 6 tahun rentan menderita Diare karena beberapa faktor seperti perilaku mencuci tangan dan perilaku makan yang kurang baik. Kuman - kuman diare masuk ke mulut melalui tangan yang telah menyentuh kotoran atau air yang terkontaminasi. Selain itu perilaku makan yang kurang baik seperti mengambil kembali makanan yang jatuh, juga kebiasaan jajan sembarangan di luar rumah tanpa memperhatikan kebersihannya turut mendukung peningkatan kejadian Diare pada anak (Fatmawati, 2017). Diare pada dasarnya merupakan gangguan pada pola eliminasi fekal dimana frekuensi defekasi meningkat dan konsistensi feses yang encer. Hal ini yang kemudian menimbulkan berbagai masalah kesehatan pada penderitanya. Menurut Suharyono, sebagai akibat dari Diare akut maupun kronis dapat terjadi hal - hal seperti kehilangan air dan elektrolit, hipoglikemia, gangguan gizi, dan gangguan sirkulasi. Bila tidak segera ditolong, maka penderita dapat meninggal (Susilaningrum, Nursalam, \& Utami, 2013).

\section{METODE}

\section{Desain, Tempat dan Waktu}

Desain studi kasus yang dilaksanakan adalah penelitian deskriptif. Penelitian deskriptif merupakan penelitian dengan melalui pengamatan (observasi) baik secara langsung maupun tidak langsung. Studi kasus dilakukan di RS TK II Pelamonia Makassar ruangan Dahlia pada tanggal 2 - 4 September 2019.

\section{Jumlah dan cara pengambilan subjek}

Subjek studi kasus terdiri dari satu klien dengan kasus Diare dengan gangguan pemenuhan kebutuhan pola eliminasi $B A B$, dengan kriteria inklusi (Pasien anak yang didiagnosa Diare dengan gangguan pola eliminasi $\mathrm{BAB}$, pasien anak usia prasekolah dengan rentang usia 3 - 5 tahun,pasien anak yang dirawat inap, orang tua / wali yang bersedia menjadi responden ) dan kriteria eksklusi (Pasien anak dengan data tidak lengkap, pasien dan orang tua / wali yang menolak menjadi responden)

\section{HASIL}

Klien adalah seorang anak perempuan bernama An. B berumur 4 tahun, beragama Islam dan belum bersekolah.Pasien dengan kasus diare didapatkan data ibu klien mengatakan klien BAB sebanyak $5 x$. lbu klien mengatakan $B A B$ klien berbentuk encer, terdapat ampas dan berwarna coklat. Ibu klien mengatakan klien mengeluh sakit perut. Ibu klien juga mengatakan klien muntah-muntah sebanyak 7 kali. Peristaltik usus klien meningkat yaitu $35 \mathrm{x} /$ menit.lbu klien mengatakan klien sehari - hari tinggal di rumah bersama orang tua dan neneknya, namun orang tua klien tidak bisa sering mengawasi klien karena kedua orang tua klien bekerja. Klien biasanya sering bermain di luar rumah. Berdasarkan pemeriksaan laborarorium hasil analisa feses menunjukkan bakteri negatif, amoeba negatif, Ascaris sp negatif, Trichiuris $s p$ negatif, dan Ancylostoma $s p$ negatif. Sementara hasil pemeriksaan darah didapatkan leukosit meningkat 
yaitu 2-3 sel/LP. Terapi yang diberikan pada klien adalah cairan intravena,Ringer Lactat (RL) $16 \mathrm{tpm}$, Paracetamol $120 \mathrm{ml}$, Zinkid $10 \mathrm{ml} / 24$ jam, Omedom sirup $25 \mathrm{ml} / 8 \mathrm{jam}$, dan Cefixime $4 \mathrm{mg} /$ 12 jam. Identifikasi penyebab Diare (mis. Infamasi gastrointestinal, iritasi gastrointestinal, proses infeksi, malabsorpsi, ansietas, stress, efek obat-obatan, pemberian botol susu), Identifikasi riwayat pemberian makanan, monitor warna, volume, frekuensi, dan konsistensi tinja, observasi tanda-tanda vital, observasi bising usus, berikan cairan intravena, berikan kompres air hangat jika terjadi demam,edukasi : anjurkan menghindari makanan pembentuk gas, pedas, dan mengandung laktosa, kolaborasi pemberian obat antidiare,pemberian obat antibiotik,kolaborasi pemberian obat antipiretik sangat membantu dalam penangan pola eliminasi diare.

\section{PEMBAHASAN}

Berdasarkan hasil penelitian pada studi kasus yang terjadi pada An. B dengan diagnosa medis Gastroenteritis Akut (GEA) maka pada bagian ini peneliti akan menguraikan hasil yang diperoleh selama pelaksanaan studi kasus yang meliputi : Frekuensi defekasi eliminasi BAB meningkat. Peningkatan frekuensi defekasi disebabkan oleh transportasi air dan elektrolit yang abnormal dalam usus (Wong, 2009). Tekanan osmotik dalam rongga usus meninggi, sehingga terjadi pergeseran air dan elektrolit ke dalam rongga usus. Isi rongga usus yang berlebihan merangsang usus mengeluarkannya sehingga timbul Diare (Wijaya \& Putri, 2013). Meningkatnya mobilitas dan cepatnya pengosongan pada intestinal merupakan akibat dari gangguan absorbs dan ekskresi cairan dan elektrolit yang berlebih (Suriadi \& Yuliani, 2010). Konsistensi feses encer; Perubahan konsistensi feses menjadi encer terjadi karena adanya peningkatan sekresi air dan elektrolit ke dalam rongga usus yang menyebabkan peningkatan isi rongga usus. Hiperperistaltik mengakibatkan berkurangnya kesempatan usus untuk menyerap makanan. Pada kasus diare feses berbentuk cair karena kandungan air lebih banyak dari biasanya lebih dari $200 \mathrm{gram}$ atau $200 \mathrm{ml} / 24$ jam (Wijaya \& Putri, 2013). Hiperperistaltik usus: Pergeseran air dan elektrolit kedalam rongga usus menyebabkan isi rongga usus berlebihan. Hal ini merangsang usus untuk mengeluarkannya sehingga timbul Diare (Susilaningrum, Nursalam, \& Utami, 2013). Produk pencernaan bergerak di sepanjang usus karena adanya kerja peristalsis yang menciptakan suara jelas yang dapat didengar dengan stetoskop. Kerja usus karena isi rongga usus yang berlebihan menimbulkan hiperperistaltik usus (Rosdal \& Kowalski, 2014). Selain itu, hiperperistaltik usus dapat disebabkan oleh bahan-bahan kimia, makanan (seperti keracunan makanan, makanan yang pedas atau terlalu asam), gangguan psikis (ketakutan, gugup), gangguan saraf, hawa dingin, alergi (Sodikin, 2011). Peningkatan suhu tubuh: Demam pada Diare terjadi karena adanya stimulus infeksi. Infeksi yang terjadi dapat menyebabkan reaksi inflamasi. Reaksi inflamasi tersebut merangsang keluarnya zat pirogen seperti endogen dan eksogen (bradikinin, serotonin, prostaglandin, dan histamin), zat tersebut mempengaruhi pengatur suhu tubuh di hipotalamus yang menyebabkan peningkatan suhu tubuh dan terjadi demam (Zahroh \& Khasanah, 2017). Berdasarkan pengkajian dan analisa data yang dilakukan peneliti, didapatkan diagnosa keperawatan sesuai dengan masalah keperawatan yang dialami pasien yaitu: Gangguan Pola Eliminasi: Diare Berhubungan dengan Proses Infeksi.Gangguan pola eliminasi: Diare merupakan gangguan fungsi penyerapan dan sekresi yang terjadi di saluran pencernaan ditandai dengan pola buang air besar yang tidak normal dengan bentuk tinja encer serta adanya peningkatan frekuensi $B A B$ yang lebih dari biasanya (Zahroh \& Khasanah, 2017). Menurut Mansjoer dkk (2003), penyebab Diare dapat dibagi dalam beberapa faktor yaitu faktor infeksi, faktor malabsorbsi, faktor makanan, dan faktor psikologis (Wijaya \& Putri, 2013). Adapun tindakan keperawatan yang dilakukan untuk mengatasi masalah keperawatan pada klien antara lain: mengkaji warna, frekuensi dan konsistensi tinja. Pada kasus Diare terjadi gangguan fungsi penyerapan dan sekresi yang terjadi di saluran pencernaan sehingga pola buang air besar tidak normal dan bentuk tinja encer karena kandungan air lebih banyak dari normal yakni $100-200 \mathrm{ml}$ sekali defekasi (Zahroh \& Khasanah, 2017). Karakteristik feses perlu diketahui untuk memonitor perkembangan klien dan efektifitas terapi. Mengidentifikasi penyebab diare: Diare dapat disebabkan oleh inflamasi gastrointestinal, iritasi gastrointestinal, proses infeksi, malabsorpsi, ansietas, stress, efek obat-obatan maupun pemberian botol susu. Mengetahui penyebab diare penting untuk dapat menentukan intervensi yang tepat. Mengidentifikasi riwayat pemberian makanan. Kuman infeksi penyebab diare ditularkan melalui jalur pekal oral, yaitu dengan memasukkan cairan atau benda yang tercemar dengan tinja, misalnya air minum, tangan atau jari-jari, pengelolaan makanan yang kurang bersih, maupun makanan yang disiapkan dalam tempat yang terkontaminasi air yang tercemar (Wijaya \& Putri, 2013). Mengobservasi tanda - tanda vital. Pada kasus Diare sering terjadi peningkatan suhu tubuh. Hal ini terjadi karena adanya reaksi inflamasi (Zahroh \& Khasanah, 2017). Selain itu tanda - tanda vital di monitor untuk mengetahui keadaan umum pasien. Mengobservasi bising usus. Pada kasus Diare terjadi hiperperistaltik usus. Hal ini merupakan reaksi tubuh untuk 
melakukan pengosongan usus karena isi usus yang berlebihan akibat pergeseran air dan elektrolit ke dalam rongga usus.. Memberikan cairan intravena.Pemberian cairan cepat melalui IV line sebagai pengganti cairan yang hilang (Wijaya \& Putri, 2013) Salah satu prinsip pengobatan Diare adalah pasien dengan Diare membutuhkan penggantian cairan dan elektrolit tanpa melihat etiologinya (Sodikin, 2011). Memberi kompres hangat dapat membuka pori-pori, sehingga panas pada tubuh keluar melalui pori-pori tersebut. Tindakan keperawatan ini dapat dilakukan sewaktu-waktu sesuai dengan kondisi klien. Menganjurkan menghindari makanan pembentuk gas, pedas, dan mengandung laktosa. Makanan yang pedas atau terlalu asam,dapat menyebabkan hiperperistaltik usus (Sodikin, 2011). Sedangkan makanan yang mengandung laktosa dapat menimbulkan malabsorbsi (Wijaya \& Putri, 2013). Memberikan obat antidiare .Pemberian obat zink selama dan setelah serangan Diare dapat menurunkan tingkat keparahan Diare. Memberikan obat antibiotic. Antibiotic diberikan pada kasus Diare yang disebabkan oleh infeksi. Memberikan obat antipiretik; paracetamol merupakan obat yang masuk dalam golongan antipiretik yang dapat menurunkan demam. Gangguan pola eliminasi : Diare merupakan gangguan fungsi penyerapan dan sekresi yang terjadi di saluran pencernaan ditandai dengan pola buang air besar yang tidak normal dengan bentuk tinja encer serta adanya peningkatan frekuensi $B A B$ yang lebih dari biasanya (Zahroh \& Khasanah, 2017). Menurut Mansjoer dkk (2003), penyebab Diare dapat dibagi dalam beberapa faktor yaitu faktor infeksi, faktor malabsorbsi, faktor makanan, dan faktor psikologis (Wijaya \& Putri, 2013). Data Subjektif : ibu klien mengatakan klien BAB sebanyak $5 x$ sejak sehari yang lalu. Ibu klien mengatakan klien $B A B$ sebanyak $x$ sehari. Ibu klien mengatakan $B A B$ klien berbentuk encer, terdapat ampas dan berwarna coklat. Ibu klien mengatakan klien mengeluh sakit perut. Data Objektif : Peristaltik usus klien : $35 \mathrm{x} /$ menit, Suhu $38^{\circ} \mathrm{C}$, Leukosit meningkat 2-3 sel/LP, Klien tampak lemas dan mata cekung. Rencanaan keperawatan disusun sesuai dengan kondisi klien berdasarkan standar intervensi keperawatan Indonesia menurut PPNI (2018). Adapun intervensi diagnosa Gangguan pola eliminasi : Diare berhubungan dengan proses infeksi antara lain: Identifikasi penyebab Diare (mis. Infamasi gastrointestinal, iritasi gastrointestinal, proses infeksi, malabsorpsi, ansietas, stress, efek obat-obatan, pemberian botol susu), Identifikasi riwayat pemberian makanan, monitor warna, volume, frekuensi, dan konsistensi tinja, observasi tanda-tanda vital, observasi bising usus, berikan cairan intravena, berikan kompres air hangat jika terjadi demam,edukasi : anjurkan menghindari makanan pembentuk gas, pedas, dan mengandung laktosa, kolaborasi pemberian obat antidiare,pemberian obat antibiotik,kolaborasi pemberian obat antipiretik. Setelah dilakukan tindakan keperawatan selama 3 hari diagnosa gangguan pola eliminasi : Diare berhubungan dengan proses infeksi pada An. B dapat teratasi dengan hasil pola eliminasi defekasi teratur, diare berkurang atau tidak terjadi,keseimbangan cairan meningkat dan tidak terjadi komplikasi

\section{KESIMPULAN}

Pada diagnosa keperawatan gangguan pola eliminasi: Diare berhubungan dengan proses infeksi tindakan observasi karakteristik tinja, penyebab diare, observasi peristaltic usus, edukasi pada keluarga dan kolaborasi pemberian intra vena obat anti diare, antipieretik serta antibiotic memberi pengaruh dalam mengatasi diare denga dengan hasil pola eliminasi defekasi teratur, diare berkurang atau tidak terjadi,keseimbangan cairan meningkat dan tidak terjadi komplikasi

\section{SARAN}

Diharapkan agar peneliti selanjutnya melakukan penelitian pengaruh kehadiran keluarga dalam penangan pasien diare terhadap respon hospitalisasi

\section{UCAPAN TERIMA KASIH}

Prodi D III Keperawatan Fakultas Kedokteran dan Ilmu Kesehatan, Direktur dan staf pengelola Rumah Sakit Tingkat II Pelamonia serat Kepala Ruangan Anak.

\section{DAFTAR PUSTAKA}

Artha, R. A., Indra, R. L., \& Rasyid, T. A. (2018). Faktor-Faktor yang Berhubungan dengan Eliminasi Fekal pada Pasien yang Dirawat di ICU. Jurnal Riset Kesehatan , 1-2.

Fatmawati. (2017). Faktor yang Mempengaruhi Kejadian Diare Anak. Journal of Islamic Nursing , 25-26.

Hidayat, A. A. (2017). Metodologi Penelitian Keperawatan dan Kesehatan. Jakarta: Salemba Medika.

Kemenkes. (2018). Hasil Utama Riskesdas. Indonesia: Kementrian Kesehatan Repubik Indonesia. 
PPNI. (2018). Standar Intervensi Keperawatan Indonesia : Definisi dan Tindakan Keperawatan, Edisi 1. Jakarta: DPP PPNI.

Ronalyw. (2018). Pasien Diare Terbanyak di RSUD Daya. Berita Kota Makassar , 1.

Rosdal, C. B., \& Kowalski, M. T. (2014). Buku Ajar Keperawatan Dasar. Jakarta: EGC.

Sodikin. (2011). Asuhan Keperawatan Anak : Gangguan Sistem Gastrointestinal dan Hepatobilier. Jakarta: Salemba Medika.

Suraatmaja, S. (2010). Gastroenterologi. Jakarta: Kapita Selekta.

Suriadi, \& Yuliani, R. (2010). Asuhan Keperawatan pada Anak. Jakarta: CV. Sagung Seto.

Susilaningrum, R., Nursalam, \& Utami, S. (2013). Asuhan Keperawatan Bayi dan Anak : untuk Perawat dan Bidan. Jakarta: Salemba Medika.

Wijaya, A. S., \& Putri, Y. M. (2013). KMB 1 Keperawatan Medikal Bedah : Keperawatan Dewasa Teori dan Contoh Askep. Yogyakarta: Nuha Medika.

Wong, D. L. (2009). Buku Ajar Keperawatan Pediatrik Wong. Jakarta: EGC.

Zahroh, R., \& Khasanah, N. (2017). Efektifitas Pemberian Kompres Air Hangat dan Sponge Bath Terhadap Perubahan Suhu Tubuh Pasien Anak Gastroenteritis. Jurnal Ners Lentera , 35. 